\title{
Tibial lengthening in achondroplasia patients aged 6-9 years as the first stage of growth correction
}

\author{
T.I. Menshchikova, A.M. Aranovich
}

Ilizarov National Medical Research Centre for Traumatology and Orthopedics, Kurgan, Russian Federation

\begin{abstract}
Background Height increase and improvement of body proportions for achondroplasia patients normally require two or more stages of reconstructive treatment to be followed by rehabilitation between lengthening periods, and growth correction can take a significant part of life in the cohort of patients. What is the best age to start growth correction is an important question. The purpose of this paper was to present an argument for arranging the first stage of growth correction in achondroplasia patients aged 6-9 years based on the structural and functional muscle evaluation of tibiae to be lengthened. Material and methods Achondroplasia patients aged 6-9 years $(n=30)$ were examined preoperatively, during distraction, fixation and at 1.5 to 2 years of frame removal. Tibial lengthening was produced monofocally and bifocally. Contractile force of the dorsal and plantar flexion muscles of the foot was measured with dynamometer. Ultrasonography of tibial muscles was performed with HITACHI ultrasound imaging device (Japan). Results Achondroplasia patients aged 6-9 year who underwent tibial lengthening of at least $50 \%$ of the initial length developed neuropathy in $2.6 \%$ of cases and soft tissue inflammation in $5.6 \%$ of cases. Characteristic muscle striation of $\mathrm{m}$. tibialis anterior and $\mathrm{m}$. extensor digitorum longus appeared to restore at 1.5 to 2 years of tibial lengthening with clear contouring of the intermuscular septa and retained contractile force of the muscles. The contractile force restored to $96.15 \%$ of preoperative level in the anterior tibial muscles, and to $101.92 \%$ in the posterior muscles. Conclusion The comprehensive clinical, ultrasonographic and dynamometric evaluation of tibial muscles presented a good argument for tibial lengthening in achondroplasia patients aged 6-9 years. Regained muscle striation and spare capacity of $\mathrm{m}$. tibialis anterior and extensor digitorum longus, the restored force of the anterior tibial muscles to $96.15 \%$ of the preoperative level suggested the possibility for the next stage of growth correction. Keywords: achondroplasia, transosseous osteosynthesis, distraction, fixation, functionality, ultrasonography, dynamometer, muscle structure, $\mathrm{m}$. tibialis anterior, $\mathrm{m}$. extensor digitorum longus
\end{abstract}

\section{INTRODUCTION}

The leading symptoms of achondroplasia patients include shortening and deformity of the limb segments, a pronounced disproportion between the trunk and the limbs. Achondroplasia patients have an adult height of 122 to $130 \mathrm{~cm}$. The physeal dysplastic phenotype is common to the disease that is inherited as an autosomal dominant trait [1-4]. The condition occurs in 1 in 100,000 newborns. Achondroplasia is caused by a mutation in fibroblast growth factor receptor 3 (FGFR3) gene that is mapped on chromosome 1p16.3 and is a FGFR family member. Geneticists have identified the replacement of glycine with arginine at position 380 (Gly380arg) in the FGFR3 polypeptide that results in a pronounced impairment of muscle development $[5,6]$. The use of hormone therapy in achondroplasia is ineffective [7]. Short stature, a sharp disparity between the trunk and the limb length is not only a cosmesis disadvantage but also creates numerous physical and social problems for the patient causing difficulties in using household appliances, transportation services, clothing and everything that is designed for normal human stature $[8,9]$. A radical technical solution to height increase for achondroplasia patients was offered in the second half of the last century due to the introduction of the method of transosseous distraction osteosynthesis developed by G.A. Ilizarov. This is the only method to date that can help people of short stature $[1,8,10]$. The use of the Ilizarov apparatus allows for limb lengthening by the amount being comparable to the original length, a clear surgical plan of the lengthening stages and the sequence is to be devised with rehabilitation periods provided inbetween. The final outcome would be dependent on a number and severity of adverse events that can occur because of the amount of elongation, the duration of treatment and postoperative recovery and the patient's age. All these factors must be considered for surgical growth correction $[8,11,13,14]$. Although transosseous osteosynthesis has been employed for limb lengthening for more than 40 years the question of the best age to start growth correction is still controversial. Many authors suggest that children aged 6-9 years can undergo limb lengthening as early as possible with elastic soft tissues and bones having higher osteogenic capacity. The need for early surgical treatment of achondroplasia patients can be ascribed to the complexity of the pathology that usually requires two or more stages of reconstructive 
treatment, and growth correction can take a significant part of life in the cohort of patients. Limb lengthening in achondroplasia patients aged under 10 years can help to avoid interference in the educational process in adolescence [15].

The first stage of treatment performed for children aged 6 years is one of the important principles for achieving a favorable outcome [16]. Restrictions of limb lengthening in this age group are associated with psychological problems when the child cannot understand the purpose of the procedure [17]. Frank Schiedel and Robert Rödl report that involvement of the child in decision-making at the start of treatment can be recommended from the age of 12 [18]. Ganel A., Horoszowski H. advised to start limb elongation of male achondroplasia patients at the age of 8 years or older, and to delay limb lengthening in female achondroplasia patients until approximately 15 years of age to facilitate maximal skeletal growth [19].

The natural growth of lower limbs is accompanied by increased muscle strength in healthy children, and achondroplasia patients are likely to develop such complications as neuropathy, decreased muscle strength, knee joint contractures, and restriction of active dorsiflexion of the foot with increased anthropometric dimensions [12, 20-23]. A comparative analysis of outcomes of surgical treatment has shown that limb lengthening in childhood is accompanied by a significantly lower rate of neurological complications, and rehabilitation aimed at restoring nerve conduction appears to be more effective at this age $[11,12]$.

A large number of studies report clinical aspects of the Ilizarov operative limb lengthening [23-26]. There is a limited number of papers describing the structural changes of soft tissues and the functionality of the lower limbs after leg lengthening in achondroplasia children aged 6-9 years. The importance of the study is attributed to multi-stage treatment, the wish to increase stature as much as possible and improve the quality of life. There is an increasing number of achondroplasia children of preschool and primary school age seen at the hospital of the Kurgan Ilizarov Center to have the first stage of growth correction to be performed there.

The purpose of this paper was to present an argument for arranging the first stage of growth correction in achondroplasia patients aged 6-9 years based on the structural and functional muscle evaluation of tibiae to be lengthened.

\section{MATERIAL AND METHODS}

The study included patients aged 6-9 years diagnosed with achondroplasia, having a height of 93-97 cm and ambulating unassisted. Patients with hypo - and pseudoachondroplasia, achondroplasia patients who had had corrective surgery on the lower limbs, patients with paresis of the lower limbs were excluded from the study. The resultant cohort consisted of 30 patients ( 16 female and 14 male patients). The average age of the patients was $7.5 \pm 1.5$ years (from 6 to 9 years). All patients underwent anthropometric examinations to identify the amount to be lengthened. The stature of patients aged 6-7 years did not exceed $98 \pm 1.0 \mathrm{~cm}$. The tibial length of achondroplasia patients aged 6-7 years and 8-9 years was $16.25 \mathrm{~cm}$ and $17.5 \mathrm{~cm}$, respectively, and that of healthy peers in these age groups was $24 \mathrm{~cm}$ (length deficit - $32 \%$ ) and $30 \mathrm{~cm}$ (length deficit $-41.7 \%$ ), respectively. The 30 children were examined in dynamics. Ultrasound of the tibial muscles was performed preoperatively, at $10,20,30,60$ days of distraction, at 30 and 60 days of fixation and at 30 to 45 days of frame removal. Dynamometry was performed preoperatively and at 1 year to 1.5 years of frame removal.

Tibial lengthening was performed using monofocal distraction osteosynthesis, bifocal distraction osteosynthesis of both tibiae, bifocal distraction osteosynthesis of tibia and monofocal osteosynthesis of fibula. Tibiae were lengthened sequentially.The function of the knee joints and lateral laxity were shown to improve after tibial lengthening and deformity correction. The distraction rate was maintained at $0.25 \mathrm{~mm} \times 4$ times a day (through bifocal lengthening at each level) to prevent premature consolidation and to gain the length preplanned.

Tibial muscle power was measured with a testing facility specially designed at the Federal State Budgetary Institution "National Ilizarov Medical Research Centre for Traumatology and Ortopaedics" [27]. Ultrasonography of $\mathrm{m}$. tibialis anterior, $\mathrm{m}$. extensor digitorum longus, m. gastrocnemius, m.soleus was produced with HITACHI ultrasound imaging device (Japan) using a 7.5 MHz transducer. The muscle power was measured at rest with the subjects lying supine or on the stomach to assess the anterior and posterior tibial muscles. The transducer was placed along the longitudinal axis of the limb segment at the level of the belly of the muscle. The thickness of the muscles was determined using mobile markers, and a histogram was constructed using a standard computer program to assess the acoustic density (AD) of the muscles. 


\section{RESULTS}

The structure of the anterior and posterior tibial muscles in achondroplasia patients was evaluated ultrasonographically in dynamics preoperatively and at different time points of rehabilitation. The bundles of muscle fibers appeared to have a vague orientation preoperatively in achondroplasia patients aged 6 to 7 years that was associated with deficient muscle maturity in children at this age (Fig. 1). The thickness of m. tibialis anterior and $\mathrm{m}$. extensor digitorum longus was increased by $38 \%$ under static stress with acoustic density (AD) reduced by 7 and $22.7 \%$ as compared to the baseline.

Dynamic ultrasound revealed the severity of destructive changes in the tibial muscles observed throughout the distraction and fixation periods. Subcutaneous cellular tissue and muscles appeared to be swollen as the first soft tissue response to limb lengthening being associated with alterations in bone and soft tissues. This was sonographically manifested by decreased $\mathrm{AD}$ and an increased thickness of the subcutaneous cellular tissue and muscle complex. The accelerated growth of the lower limb segments resulted in a gradual disarrangement of the bundles of muscle fibers under tension stress with thinning of the muscle layers, irregular contours, impaired muscle differentiation and striation that indicated to muscle atrophy. The severity of these changes was mostly dependent on the initial muscle condition, patient's age, the rate of distraction and the amount of lengthen to be gained. Pronounced structural changes in the direction of the bundles of muscle fibers were seen in the anterior tibial muscles after $10 \pm 2$ days at a distraction rate of $0.25 \times 4 \mathrm{~mm}$ per day (Fig. 2).

Further distraction led to greater disarrangement of the muscle structure with impaired muscle striation, thinning of the intermuscular septum, thickness of m. tibialis anterior, $\mathrm{m}$. extensor digitorum longus decreased by 25 and $28 \%$, respectively, at 60 days as compared to the intact segment. The acoustic density of the muscles increased by $30 \pm 4.50 \%(\mathrm{p} \leq 0.05)$ and by $50 \pm 6.90 \%$ $(p \leq 0.05)$, respectively, at the end of the distraction as compared to the baseline measurements. Impaired muscle structure seen in patients aged 6-9 years at early distraction period was associated with the lack of maturity. Absence of clear orientation in the bundles of muscle fibers was typical for both healthy children and achondroplasia patients (Fig. 3).
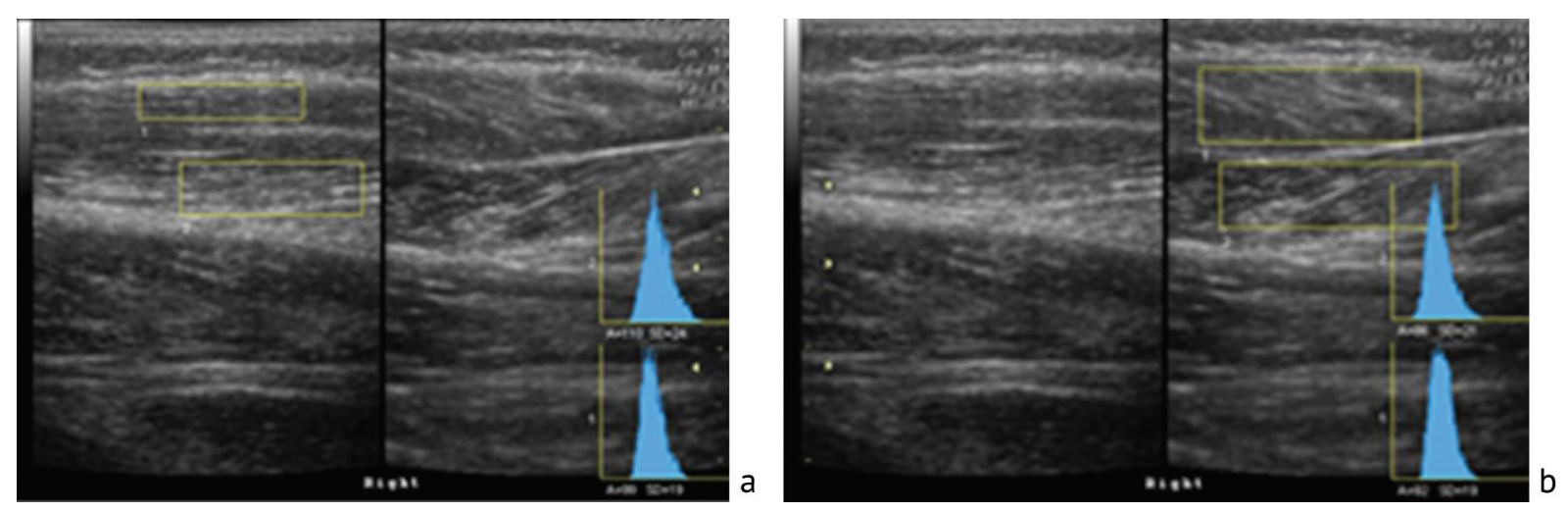

Fig. 1 Ultrasonographic scans of the anterior tibial muscles of a 7-year-old patient diagnosed with achondroplasia, low stature; histograms were built with conventional radiographs to demonstrate ultrasonic muscle parameters of $(\boldsymbol{a}) \mathrm{m}$. tibialis anterior at rest measuring $99 \mathrm{CU}$; m. extensor digitorum longus $110 \mathrm{CU}$; (b) m. tibialis anterior at static stress $92 \mathrm{CU}$; m. extensor digitorum longus $85 \mathrm{CU}$
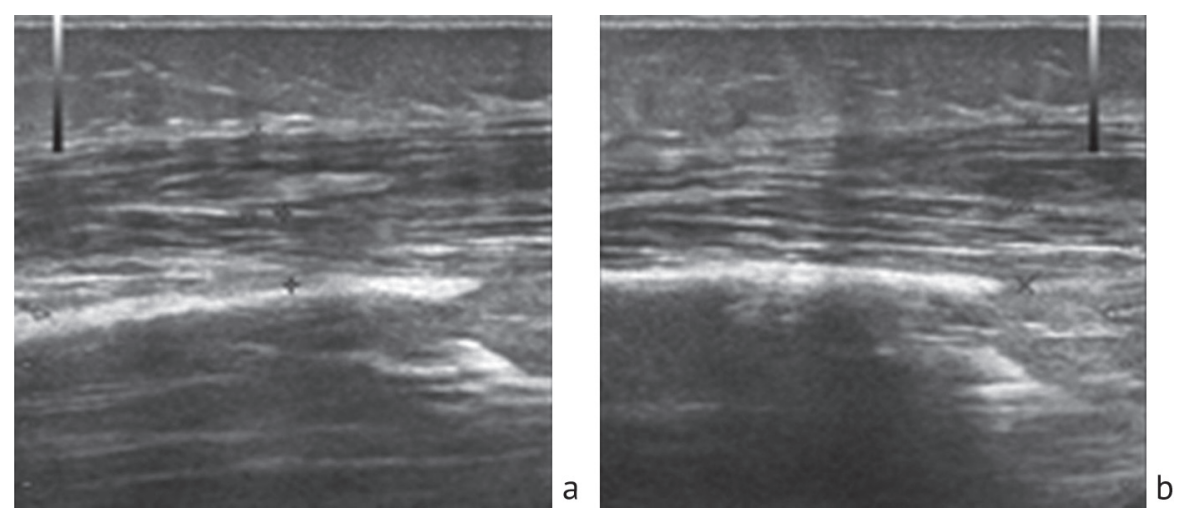

Fig. 2 Sonographic scans of the anterior tibial muscles of a 7-year-old patient K. showing impaired muscular striation, contouring of the intermuscular septum at 12-day distraction of the right tibia; thickness at rest $(\boldsymbol{a})$ and under static stress (b) measured $6 \mathrm{~mm}$ for $\mathrm{m}$. tibialis anterior and $4.7 \mathrm{~mm}$ for $\mathrm{m}$. extensor digitorum longus; acoustic density measured $124.4 \mathrm{CU}$ for $\mathrm{m}$. tibialis anterior and $141 \mathrm{CU}$ for $\mathrm{m}$. extensor digitorum longus 

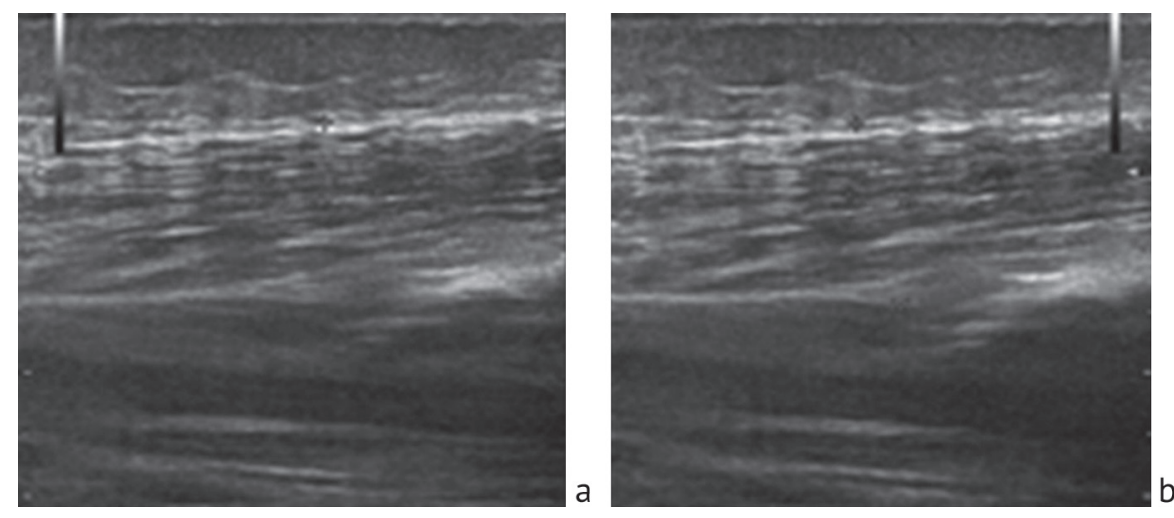

Fig. 3 Sonographic scans of the anterior tibial muscles of the 7-year-old patient K. showing impaired muscular striation, indiscriminate contouring of the intermuscular septum at 60-day distraction of the right tibia; thickness at rest $(\boldsymbol{a})$ and under static stress $(\boldsymbol{b})$ measured $5.8 \mathrm{~mm}$ for $\mathrm{m}$. tibialis anterior and $4.2 \mathrm{~mm}$ for $\mathrm{m}$. extensor digitorum longus; acoustic density measured $134.4 \mathrm{CU}$ for $\mathrm{m}$. tibialis anterior and $148 \mathrm{CU}$ for $m$. extensor digitorum longus
The muscles' contours appeared to realign during the fixation period but structural changes persisted with the acoustic density increased to $158 \pm 12 \mathrm{CU}$ and the directionality of the bundles of muscle fibers impaired. An example is the sonographic scans of the anterior tibial muscles of the 7-year-old patient K. (Fig. 4).

The structure of $\mathrm{m}$. tibialis anterior and $\mathrm{m}$. extensor digitorum longus regained characteristic muscular striation, clearly differentiated intermuscular septa, the contractile response at one-year follow-up with the acoustic density of $\mathrm{m}$. tibialis anterior and $\mathrm{m}$. extensor digitorum longus measuring $135 \pm 10 \mathrm{CU}$ and $139 \pm 8.6 \mathrm{CU}$, respectively (Fig. 5).

With greater mass of the posterior tibial muscles the structural changes appeared to be less pronounced during distraction. The differentiation of the muscle layers in the $\mathrm{m}$. gastrocnemius and $\mathrm{m}$. soleus persisted throughout the entire treatment period, and the acoustic density increased by $19 \%$ as compared to the baseline level measuring $134 \pm 19 \mathrm{CU}$. The contractile capacity of the muscles was evaluated using a dynamometer stand to determine functionality of the musculoskeletal system after tibial lengthening. Dorsiflexion muscles of the foot were shown to recover by $96.15 \%$ of the baseline level (under-recovery was $3.85 \%$ ) at 1.5 to 2 years of frame removal following tibial lengthening of 6-7 cm, and the plantar flexion muscles appeared to be completely restored (101.92\%) (Table 1). The findings indicated to a correctly selected value of tibial length to be gained, maintained muscles' capabilities and adequate rehabilitation arranged for the patients of this age group.
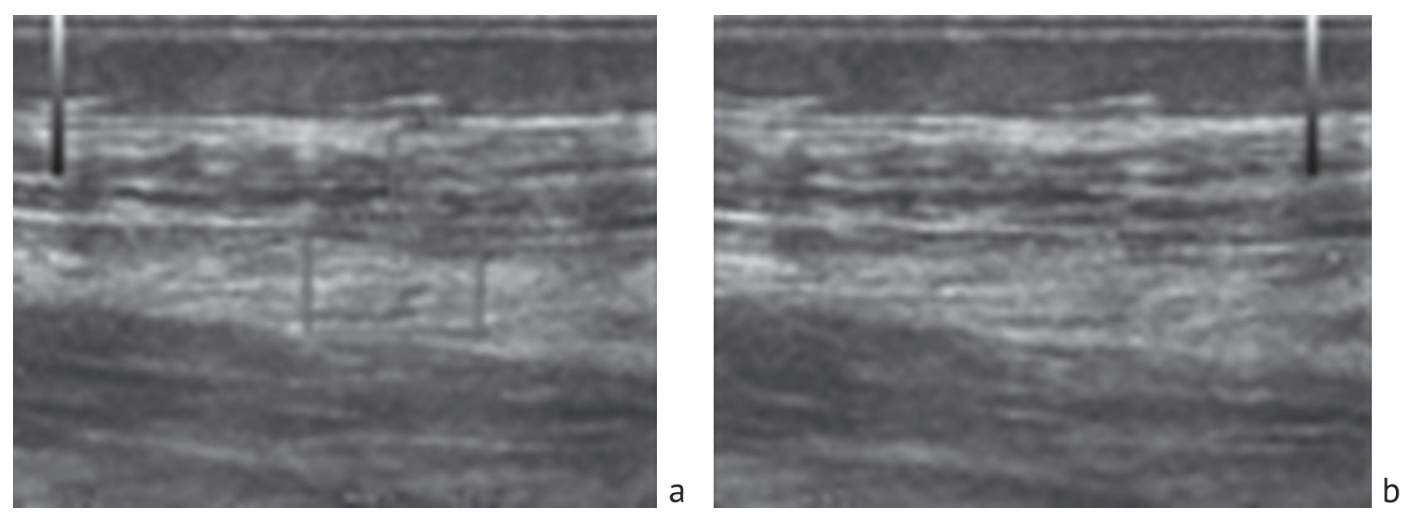

Fig. 4 Sonographic scans of the anterior tibial muscles of the 7-year-old patient K. showing impaired muscular striation, indiscriminate contouring of the intermuscular septum at 60-day fixaction of the right tibia; thickness at rest $(\boldsymbol{a})$ and under static stress (b) measured $5.8 \mathrm{~mm}$ for $\mathrm{m}$. tibialis anterior and $4.2 \mathrm{~mm}$ for $\mathrm{m}$. extensor digitorum longus; acoustic density measured 140.4 CU for $\mathrm{m}$. tibialis anterior and $155 \mathrm{CU}$ for $\mathrm{m}$. extensor digitorum longus

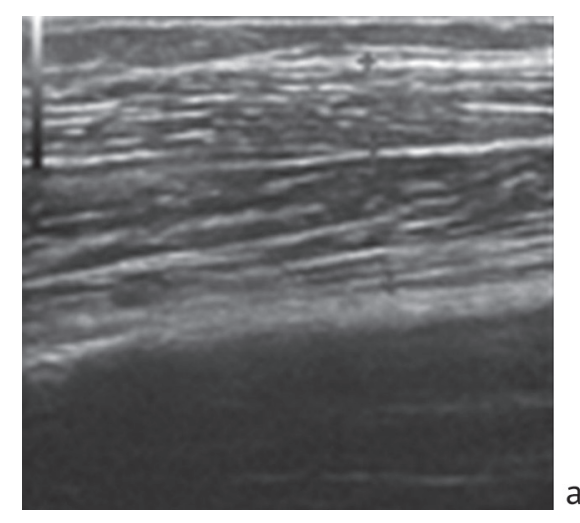

Fig. 5 Sonographic scans of the anterior tibial muscles of the 7-year-old patient K. showing discriminate contouring of the muscles, clear intermuscular septum, typical muscle striation at one-year follow-up; thickness at rest $(\boldsymbol{a})$ and under static stress (b) measured $7.7 \mathrm{~mm}$ and $10.3 \mathrm{~mm}$ for $\mathrm{m}$. tibialis anterior and $11.6 \mathrm{~mm}$ and $14.7 \mathrm{~mm}$ for $\mathrm{m}$. extensor digitorum longus; acoustic density measured $122.4 \mathrm{CU}$ and $120 \mathrm{CU}$ for $\mathrm{m}$. tibialis anterior and $114 \mathrm{CU}$ and $104 \mathrm{CU}$ for m. extensor digitorum longus 
Muscle strength of the dorsiflexion and plantar flexion muscles of the foot $(\mathrm{M} \pm \mathrm{m})$ in achondroplasia patients measured preoperatively and at 1-2 years of frame removal

\begin{tabular}{|c|c|c|c|c|c|}
\hline \multirow{2}{*}{$\begin{array}{c}\text { Age } \\
\text { (years) }\end{array}$} & \multirow{2}{*}{$\begin{array}{c}\text { Number } \\
\text { of patients }\end{array}$} & \multicolumn{2}{|c|}{ Dorsiflexion muscles of the foot } & \multicolumn{2}{c|}{ Plantar flexion muscles of the foot } \\
\cline { 3 - 6 } & pre-op & at 1-2 years of frame removal & pre-op & at 1-2 years of frame removal \\
\hline 6 & $\mathrm{n}=7$ & $0.21 \pm 0.06$ & - & $0.36 \pm 0.08$ & - \\
\hline 7 & $\mathrm{n}=8$ & $0.23 \pm 0.04$ & $0.22 \pm 0.04$ & $0.39 \pm 0.05$ & $0.38 \pm 0.05$ \\
\hline 8 & $\mathrm{n}=8$ & $0.24 \pm 0.08$ & $0.22 \pm 0.03$ & $0.46 \pm 0.05$ & $0.45 \pm 0.09$ \\
\hline 9 & $\mathrm{n}=7$ & $0.26 \pm 0.06$ & $0.25 \pm 0.06$ & $0.52 \pm 0.08$ & $0.53 \pm 0.11$ \\
\hline
\end{tabular}

\section{DISCUSSION}

Surgical growth correction in achondroplasia patients involves a multi-stage polysegmental limb lengthening and requires a rationally distributed sequence of lengthening phases $[1,2,8,10]$. However, such limb lengthening is accompanied by impaired functionality of the lower limbs with reduced muscle strength and range of motion in the joints $[1,12]$. Continuous improvements of the techniques of transosseous osteosynthesis including additional foot fixation at an angle close to $90^{\circ}$ during the distraction helps to prevent it from sagging. The functionality of the lower limbs lengthened at the first stage and well recovered after rehabilitation will be the key to the amount of length to be gained at the subsequent stages of treatment.

The first stage of limb lengthening performed for patients aged 6-9 years is normally accompanied by a minimum soft tissue complication and allows the patients improve body proportions, reduce growth retardation as compared to healthy peers, and maintain the functionality throughout the entire period of rehabilitation. The use of the ultrasonography facilitates assessment of the muscles' structure [28]. The anterior tibial muscles have been shown to undergo greater structural changes during limb lengthening due to specific anatomy: the single-joint muscle closely connected to the tibia (it begins at a greater length directly from the elongated tibia), relatively small geometric dimensions, having the strength of 3 times less than that of the antagonists. Ultrasound findings on the structure of the tibial muscles observed at 1.5 to 2 years of frame removal demonstrated clear differentiation of $\mathrm{m}$. tibialis anterior and $\mathrm{m}$. extensor digitorum longus, the presence of a contractile response, indicating to the maintained capacity of the anterior tibial muscles [29].

Dynamometry showed almost completely restored strength of the anterior tibial muscles $(96.15 \%)$ at 1.5 to 2 years of frame removal, and ultrasonographic findings indicated to maintained capacity of the muscles to facilitate the next phase of limb lengthening achieving the maximum length possible. The findings obtained are in line with the series of other authors reporting that the musculoskeletal system can quickly adapt to the new biomechanical conditions for the gait, and limb lengthening of no more than $50 \%$ of the original length is accompanied by fewer complications and allows for positive outcomes [15-17]. Low complication rate is reported in achondroplasia patients with neuropathy and soft tissue inflammation observed in $2.6 \%$ and $5.6 \%$, respectively. Complex regenerative and metabolic processes taking place in the muscles during distraction and fixation of tibial lengthening in children aged 6-7 years resulted in muscle recovery and normal morphology at 1.5 to 2 years of frame removal.

\section{CONCLUSION}

Regained muscle striation and spare capacity of $\mathrm{m}$. tibialis anterior and extensor digitorum longus, the restored force of the anterior tibial muscles to $96.15 \%$ of the preoperative level suggested the possibility for the next stage of growth correction. The comprehensive clinical, ultrasonographic and dynamometric evaluation of tibial muscles presented a good argument for tibial lengthening in achondroplasia patients aged 6-9 years.

\section{REFERENCES}

1. Popkov A.V., Shevtsov V.I. eds. Akhondroplaziia: rukovodstvo dlia vrachei [Achondroplasia: guide for physicians]. M., Meditsina, 2001, 352 p. (in Russian)

2. Daugherty A. Achondroplasia: Etiology, Clinical Presentation, and Management. Neonatal Netw., 2017, vol. 36, no. 6, pp. 337-342. DOI: 10.1891/0730-0832.36.6.337

3. Trotter T.L., Hall J.G. American Academy of Pediatrics Committee on Genetics. Health supervision for children with achondroplasia. Pediatrics, 2005, vol. 116, no. 3, pp. 771-783. DOI: 10.1542/peds.2005-1440

4. Shirley E.D., Ain M.C. Achondroplasia: manifestations and treatment. J. Am. Acad. Orthop. Surg., 2009, vol. 17, no. 4, pp. $231-241$. DOI: $10.5435 / 00124635-200904000-00004$ 
5. Satiroglu-Tufan N.L., Tufan A.C., Semerci C.N., Bagci H. Accurate diagnosis of a homozygous G1138A mutation in the fibroblast growth factor receptor 3 gene responsible for achondroplasia. Tohoku J. Exp. Med., 2006, vol. 208, no. 2, pp. 103-107. DOI: 10.1620/ tjem.208.103

6. Vasserman N.N., Shchagina O.A., Poliakov A.V. Rezultaty ispolzovaniia novoi meditsinskoi tekhnologii «Sistema detektsii naibolee chastykh mutatsii gena FGFR3, otvetstvennogo za akhondroplaziiu i gipokhondroplaziiu v DNK-diagnostike [Results of using new medical technology "A system for detecting the most frequent mutations of FGFR3 gene, responsible for achondroplasia and hypochondroplasia" in DNA-diagnosis]. Meditsinskaia Genetika, 2016, vol. 15, no. 2, pp. 37-41. (in Russian)

7. Kanaka-Gantenbein C. Present status of the use of growth hormone in short children with bone diseases (diseases of the skeleton). J. Pediatr. Endocrinol. Metab., 2001, vol. 14, no. 1, pp. 17-26. DOI: 10.1515/jpem.2001.14.1.17

8. Klimov O.V., Aranovich A.M. Povtornoe udlinenie goleni kak etap rekonstruktsii ODS patsientov s akhondroplaziei [Repeated tibial lengthening as a stage of locomotor reconstruction in achondroplasia patients]. Genij Ortopedii, 2017, vol. 23, no. 4, pp. 401-404.

9. Diachkova G.V., Aranovich A.M., Diachkov K.A., Klimov O.V., Novikov K.I., Sutiagin I.V. Ortopedicheskie, psikhologicheskie, sotsialnye i filosofskie aspekty $\mathrm{v}$ reshenii problemy lecheniia bolnykh akhondroplaziei po metodu Ilizarova [Orthopaedic, psychological, social and philosophical aspects of achondroplasia patients treated with the Ilizarov method]. Genij Ortopedii, 2018, vol. 24 , no. 4 , pp. 465-473.

10.Song S.H., Agashe M.V., Huh Y.J., Hwang S.Y., Song H.R. Physeal growth arrest after tibial lengthening in achondroplasia: 23 children followed to skeletal maturity. Acta Orthop., 2012, vol. 83, no. 3, pp. 282-287. DOI: 10.3109/17453674.2012.678802

11.Dolganov D.V., Erokhin A.N., Ershov E.V., Neretin A.S., Popkov A.V., Popkov D.A., Saifutdinov M.S., Filimonova G.N., Shchurov V.A. Vrozhdennoe ukorochenie nizhnikh konechnostei u detei [Congenital shortening of the lower limbs in children]. Ed. by Popkov A.V. Chelyabinsk, 2011, 510 p. (in Russian)

12.Aldegheri R. Distraction osteogenesis for lengthening of the tibia in patients who have limb-length discrepancy or short stature. J. Bone Joint Surg. Am., 1999, vol. 81, no. 5, pp. 624-634. DOI: 10.2106/00004623-199905000-00004.

13.Kadono I., Kitoh H., Mishima K., Matsushita M., Sato K., Kako M., Ishiguro N. Changes in the range of motion of the lower limb joints during extensive tibial lengthening in achondroplasia. J. Pediatr. Orthop. B, 2018, vol. 27, no. 6, pp. 535-540. DOI: 10.1097/ BPB.0000000000000526

14.Griffith S.I., McCarthy J.J., Davidson R.S. Comparison of the complication rates between first and second (repeated) lengthening in the same limb segment. J. Pediatr. Orthop., 2006, vol. 26, no. 4, pp. 534-536. DOI: 10.1097/01.bpo.0000226275.70706.d5

15.Chilbule S.K., Dutt V., Madhuri V. Limb lengthening in achondroplasia. Indian J. Orthop., 2016, vol. 50, no. 4, pp. $397-405$. DOI: $10.4103 / 0019-5413.185604$

16.Ilizarov G.A., Gracheva V.I., Shchurov V.A., Maltsev V.D., Saifutdinov M.S. Udlinenie nizhnikh konechnostei pri akhondroplazii [Lengthening of the lower limbs in achondroplasia]. Problemy chreskostnogo osteosinteza vortopedii itravmatologii:Zakonomernosti regeneratsii i rosta tkanei pod vliianiem napriazheniia rastiazheniia. Sb. nauch. tr. [Transosseous Osteosynthesis Problems in Orthopaedics and Traumatology: Regularities of tissue regeneration and growth under tension stress influence. Proceedings of the Scientific Conference]. KNIIEKOT. Kurgan, 1982, Issue 8, pp. 143-152. (in Russian)

17.Paley D. Lengthening reconstruction surgery of the foot and ankle for fibular hemimelia. $3^{\text {rd }}$ Meeting of the A.S.A.M.I. International: Abstr. Book. Istanbul, 2004, pp. 167-171.

18.Schiedel F., Rödl R. Lower limb lengthening in patients with disproportionate short stature with achondroplasia: a systematic review of the last 20 years. Disabil. Rehabil., 2012, vol. 34, no. 12, pp. 982-987. DOI: 10.3109/09638288.2011.631677

19.Ganel A., Horoszowski H. Limb lengthening in children with achondroplasia. Differences based on gender. Clin. Orthop. Relat. Res., 1996, no. 332, pp. 179-183. DOI: 10.1097/00003086-199611000-00024

20.Burghardt R.D., Yoshino K., Kashiwagi N., Yoshino S., Bhave A., Paley D., Herzenberg J.E. Bilateral double level tibial lengthening in dwarfism. J. Orthop., 2015, vol. 12, no. 4, pp. 242-247. DOI: 10.1016/j.jor.2015.05.006

21.Paley D. Problems, obstacles, and complications of limb lengthening by the Ilizarov technique. Clin. Orthop. Relat. Res., 1990, no. 250, pp. 81-104.

22.Bhave A., Shabtai L., Woelber E., Apelyan A., Paley D., Herzenberg J.E. Muscle strength and knee range of motion after femoral lengthening. Acta Orthop., 2017, vol. 88, no. 2, pp. 179-184. DOI: 10.1080/17453674.2016.1262678

23.Park K.W., Garcia R.A., Rejuso C.A., Choi J.W., Song H.R. Limb Lengthening in Patients with Achondroplasia. Yonsei Med. J., 2015, vol. 56, no. 6, pp. 1656-1662. DOI: $10.3349 /$ ymj.2015.56.6.1656

24.Ko K.R., Shim J.S., Chung C.H., Kim J.H. Surgical Results of Limb Lengthening at the Femur, Tibia, and Humerus in Patients with Achondroplasia. Clin. Orthop. Surg., 2019, vol. 11, no. 2, pp. 226-232. DOI: 10.4055/cios.2019.11.2.226

25.Donaldson J., Aftab S., Bradish C. Achondroplasia and limb lengthening: Results in a UK cohort and review of the literature. J. Orthop., 2015, vol. 12, no. 1, pp. 31-34. DOI: 10.1016/j.jor.2015.01.001

26.Aranovich A.M., Stogov M.V., Kireeva E.A., Menshchikova T.I. Prognozirovanie i kontrol techeniia distraktsionnogo osteogeneza. Analiticheskii obzor [Prediction and control of distraction osteogenesis course. Analytical review]. Genij Oropedii, 2019, vol. 25, no. 3, pp. 400-406.

27.Shchurov V.A., Dolganova T.I., Dolganov D.V. Ustanovka dlia izmereniia sily myshts goleni [An assembly for measuring the leg muscle strength]. Meditsinskaia Tekhnika, 2016, no. 2, pp. 37-39. (in Russian)

28.MakNelli Iu. Ultrazvukovye issledovaniia kostno-myshechnoi sistemy: prakticheskoe rukovodstvo [Ultrasound investigations of the osteomuscular system: practical guide]. M., Vidar, 2007, pp. 179-302. (in Russian)

29. Menshchikova T.I., Aranovich A.M. Otsenka rezervnykh vozmozhnostei perednei gruppy myshts goleni u bolnykh akhondroplaziei $\mathrm{v}$ protsesse udlineniia (ultrazvukovoe issledovanie) [Assessment of the reserve scopes of the anterior muscle group of the leg in patients with achondroplasia in the process of lengthening (An ultrasound study)]. Vestnik Travmatologii i Ortopedii im. N.N. Priorova, 2015, no. 3, pp. 13-19. (in Russian)

Received: 13.11 .2020

\section{Information about the authors:}

1. Tatyana I. Menschikova, Ph.D. of Biological Sciences, Ilizarov National Medical Research Centre for Traumatology and Orthopedics, Kurgan, Russian Federation, Email: tat-mench@mail.ru

2. Anna M. Aranovich, M.D., Ph.D., Professor,

Ilizarov National Medical Research Centre for Traumatology and Orthopedics, Kurgan, Russian Federation,

Email: aranovich_anna@mail.ru 